\title{
Pengembangan dan Integrasi Piranti Lunak Pendukung Sistem Akuisisi dan Reduksi Data Terowongan Angin Kecepatan Rendah Indonesia
}

\author{
Ivransa Zuhdi Pane
}

Balai Besar Teknologi Aerodinamika Aeroelastika dan Aeroakustika, BPPT, Tangerang Selatan, Indonesia Email : izpane@gmail.com

Diterima 13 Mei 2016

Disetujui 20 Juni 2016

\begin{abstract}
Data acquisition and reduction system plays important roles in a wind tunnel test and determine the validity of aerodynamic characteristics information of the test object in Indonesian Low Speed Tunnel. Although it has been modernized recently, the main software components of the system are still requiring supporting counterparts to optimize the efficiency and the effectivity of the test execution. Several supporting softwares have been engineered so far and further developments are still in progress as attempts to fulfill those needs. Coordinating both main and supporting softwares in a well manner should be considered to realize fully integrated system which functions from the pre-test to the post-test phases as well as to anticipate various possible needs in the future.
\end{abstract}

Index Terms - data acquisition and reduction system, software engineering, wind tunnel test

\section{PENDAHULUAN}

Pengujian terowongan angin merupakan rangkaian kegiatan pengukuran, akuisisi, pengolahan dan presentasi data yang dilaksanakan untuk mendapatkan informasi tentang karakteristik aerodinamika objek uji. Pada umumnya, pengujian ini dilakukan di suatu fasilitas terowongan angin dengan menghembuskan angin pada kecepatan tertentu melalui objek uji yang ditempatkan di seksi uji. Salah satu terowongan angin terbaik di Indonesia saat ini adalah Terowongan Angin Kecepatan Rendah Indonesia (TAKRI), yang berada di bawah pengelolaan Balai Besar Teknologi Aerodinamika Aeroelastika dan Aeroakustika (B2TA3). Sejak didirikan, unit kerja yang merupakan bagian dari Badan Pengkajian dan Penerapan Teknologi (BPPT) ini telah melaksanakan layanan pengujian terowongan selama lebih dari 25 tahun, dan senantiasa berupaya mengembangkan seluruh komponen sistem pengujian untuk menjaga kondisi keterkiniannya terhadap teknologi mutakhir guna mewujudkan hasil pengujian yang memuaskan pengguna layanan.
Salah satu komponen sistem pengujian yang selama beberapa tahun belakangan ini dimodernisasi adalah sistem akuisisi dan reduksi data (SARD). SARD merupakan pengendali utama aliran data dalam suatu pengujian terowongan angin di TAKRI. Sebagaimana ditunjukkan dalam Gambar 1, komponen pembentuk utama SARD adalah instrumentasi pengukuran, subsistem akuisisi data, sub-istem pengolahan data dan subsistem presentasi data. Dalam situasi nyata, data yang berasal dari pengukuran oleh instrumentasi terhadap objek uji diakuisisi oleh subsistem akuisisi data dalam bentuk data mentah. Selanjutnya, data ini ditransmisikan ke sub-sistem pengolahan data untuk dikonversi menjadi informasi aerodinamika yang dapat dipahami manusia dan dipresentasikan oleh subsistem presentasi data.

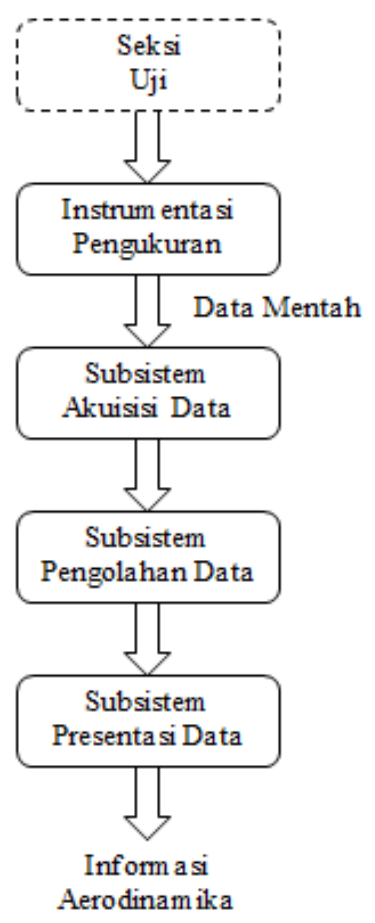

Gambar 1. Struktur SARD. 
Meskipun secara teknis telah memenuhi fungsinya sebagai pengendali aliran data uji, SARD masih belum memenuhi sejumlah tuntutan kebutuhan, khususnya yang terkait dengan aspek piranti lunak. Pertama, piranti lunak SARD saat ini belum cukup ramah terhadap pengguna dan hal ini dapat menimbulkan potensi kesalahan dalam pengoperasian SARD. Kedua, dari sudut pandang manajemen pengujian, suatu piranti lunak SARD yang ideal selayaknya tidak hanya mampu menjadi pengendali aliran data selama pengujian berlangsung, namun juga mampu menyediakan asistensi manajerial terhadap kegiatankegiatan yang dilakukan sebelum dan sesudah pengujian. Dengan kata lain, SARD seharusnya mampu mendukung kegiatan persiapan pengujian, seperti pengaturan instrumentasi uji dan pembentukan tim uji, dan kegiatan pasca-pengujian, seperti pengolahan data pasca-pengujian serta tindakan verifikasi dan validasi yang terkait. Sedangkan isu terakhir adalah skema untuk memecahkan masalah-masalah secara logis dan berkesinambungan dengan mengembangkan fungsionalitas pendukung yang dibutuhkan dan mengintegrasikannya ke dalam SARD saat ini.

Sejauh ini, sejumlah piranti lunak yang memuat fungsionalitas pendukung telah dikembangkan dan diimplementasikan pada situasi nyata, sementara beberapa lainnya masih berada dalam proses analisis dan perancangan. Terbentuknya piranti-piranti lunak pendukung terbaru dengan fungsionaltias yang berbeda ini menuntut konsiderasi yang seksama dalam menghimpun dan memadukannya dengan SARD yang telah ada agar terwujud 'kerjasama yang harmonis' antar piranti lunak utama dan para pendukungnya. Argumen tersebut memotivasi kegiatan penelitian dan pengembangan ini untuk mengusulkan mekanisme integrasi piranti lunak pendukung SARD guna mewujudkan suatu sistem yang terintegrasi secara utuh dan berfungsi mulai dari fase pra-uji hingga pasca-uji, serta mampu beradaptasi terhadap potensi pengembangan lanjut di masa depan.

Bagian selanjutnya menguraikan metodologi yang digunakan dalam pengembangan dan integrasi piranti lunak pendukung sesuai dengan disiplin rekayasa piranti lunak yang berlaku. Pembahasan mengenai fungsionalitas dan fitur utama dari piranti lunak pendukung yang telah dan akan dikembangkan diuraikan dalam bagian berikutnya. Bagian akhir menguraikan diskusi mengenai integrasi piranti lunak pendukung dan kesimpulan.

\section{METODOLOGI}

Kegiatan pengembangan piranti lunak pendukung SARD dilaksanakan dengan berlandaskan pada metodologi prototyping [1-3], sebagaimana yang ditunjukkan dalam Gambar 2. Pada prinsipnya, prototyping terdiri dari sejumlah fase tipikal, yaitu analisis, perancangan, konstruksi prototipe, serta serah terima dan umpan balik, yang secara iteratif dilaksanakan mulai dari siklus awal pengembangan, dimana piranti lunak masih berada dalam kondisi tidak sempurna, hingga secara bertahap siklus demi siklus menjadikan piranti lunak target yang sempurna.

Fase analisis adalah fase penggalian kebutuhan piranti lunak yang akan dibangun, dan dalam prototyping, fase ini berlangsung cepat dan tidak ditujukan untuk mendapatkan seluruh kebutuhan sekaligus, melainkan mengekstrak bagian per bagian dari spesifikasi utuh piranti lunak sesuai skala prioritas dalam satu siklus. Hasil dari fase analisis kemudian dimodelkan secara cepat dalam bentuk yang lebih konkret, seperti antarmuka pengguna grafis, struktur data dan algoritma, dalam fase perancangan guna mengadakan 'cetakan piranti lunak' bagi pemrogram dalam fase berikutnya, yaitu fase konstruksi prototipe. Dalam fase konstruksi ini, piranti lunak diprototipekan berdasarkan hasil dari fase perancangan dan diuji untuk memastikan kualitasnya. Selanjutnya, prototipe diserahterimakan kepada pengguna dan pihak terkait lainnya, yang kemudian diminta untuk mengevaluasi prototipe. Hasil evaluasi ini menjadi umpan balik yang dapat digunakan sebagai bahan kajian untuk menganalisis kebutuhan dan aspek perbaikan piranti lunak lebih lanjut pada siklus prototyping berikutnya.

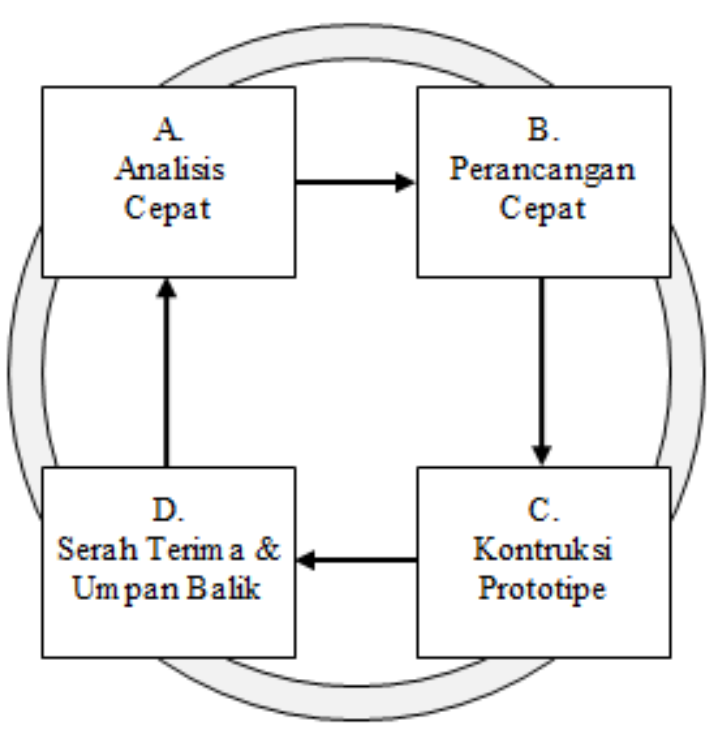

Gambar 2. Konsep prototyping.

Integrasi piranti lunak pendukung diawali dengan evaluasi fungsionalitasnya terhadap piranti lunak utama SARD yang ada. Hasil evaluasi ini memunculkan sejumlah kandidat piranti lunak pendukung yang layak untuk dipertimbangkan pengembangannya, dan kemudian ditentukan urutan waktu pengembangannya sesuai skala prioritas. Berdasarkan urutan ini, satu per satu piranti lunak pendukung dimasukkan ke dalam antrian dan mulai dibangun dengan menempatkannya pada slot kegiatan prototyping, seperti yang ditunjukkan dalam Gambar 3. Setelah pengembangannya selesai, 
maka satu piranti lunak pendukung diujicobakan integrasinya pada piranti lunak utama SARD guna memungkinkan evaluasi implementasinya dan mendapatkan umpan balik terkait lainnya untuk perbaikan lebih lanjut. Pada kasus normal, jika suatu piranti lunak pendukung dianggap berfungsi sesuai spesifikasi, maka piranti lunak pendukung yang berada di antrian berikutnya akan didorong ke slot kegiatan prototyping baru. Sebaliknya, jika suatu piranti lunak pendukung didapati bermasalah, maka piranti lunak pendukung tersebut dikembalikan ke slot kegiatan prototyping semula untuk diperbaiki lebih lanjut. Kasus eksepsional mungkin saja terjadi pada saat suatu piranti lunak pendukung yang bermasalah ternyata membutuhkan dukungan piranti lunak lainnya yang tidak terdefinisi dalam antrian dan harus dikembangkan terlebih dahulu. Dalam kasus ini, antrian akan diperbarui, dan suatu mekanisme kendali akan diberlakukan untuk mengelola perubahan.

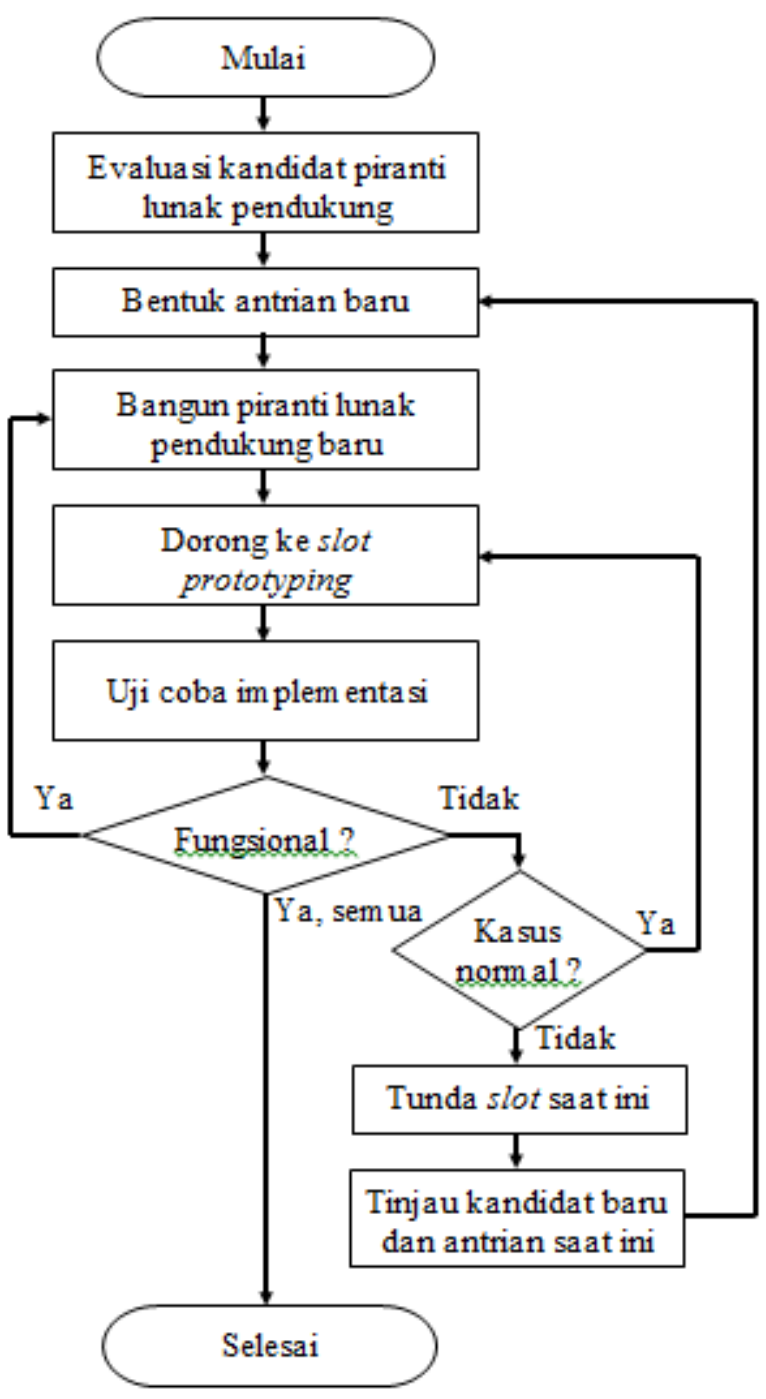

Gambar 3. Diagram alir dari prosedur integrasi.

\section{PIRANTI LUNAK PENDUKUNG SARD}

Sejumlah piranti lunak pendukung SARD telah dikembangkan untuk menjawab tuntutan kebutuhan akan dukungan fungsionalitas terhadap piranti lunak utama SARD. Berikut adalah uraian mengenai fitur dan fungsionalitas dari piranti-piranti lunak pendukung tersebut, sebagai dasar untuk konsiderasi integrasi seluruh piranti lunak yang terkait dalam operasionalitas SARD.

\section{A. Piranti Lunak Operator Akuisisi Data}

Piranti lunak operator akuisisi data dikembangkan untuk mendukung operator dalam kegiatan akuisisi data selama pengujian terowongan angin berlangsung $[4,5]$. Meskipun piranti lunak utama SARD sesungguhnya menyediakan mekanisme dasar untuk melakukan akuisisi data, kelemahan di sisi user friendly mendorong dikembangkannya piranti lunak pendukung ini. Selain faktor kenyamanan, seperti adanya fungsi penuntunan operasional secara visual dan langkah per langkah, piranti lunak pendukung ini juga dirancang untuk dapat menampilkan berbagai informasi yang terkait dengan pengujian secara fleksibel, sesuai dengan tuntutan dari pihak operator yang diutarakan pada saat analisis kebutuhan dilaksanakan.

Gambar 4 menunjukkan antarmuka pengguna grafis dari piranti lunak pendukung ini. Adapun fiturfitur utama dari piranti lunak pendukung ini adalah sebagai berikut :

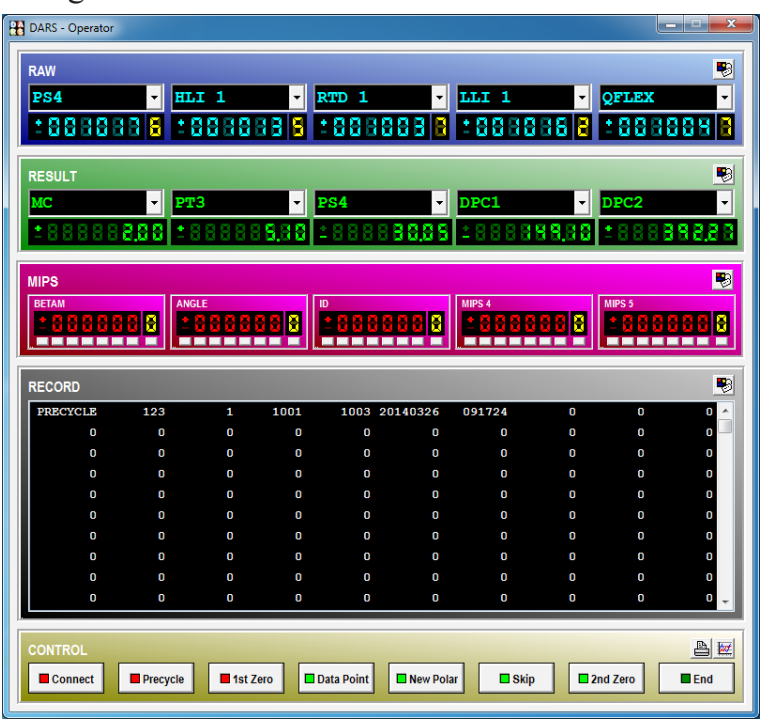

Gambar 4. Antarmuka piranti lunak operator akuisisi data.

- memungkinkan operator untuk mengedit konfigurasi pengujian melalui antarmuka yang ramah bagi pengguna,

- memungkinkan operator untuk mengeksekusi proses akuisisi data dengan prosedur yang tertuntun, sehingga mencegah terjadinya kesalahan operasional dalam proses akuisisi data 
selama pengujian berlangsung,

- menampilkan baik data mentah maupun data aerodinamika yang sudah terolah, dalam bentuk numerik dan plot/grafik secara waktu nyata,

- memungkinkan operator memilih data yang ingin ditampilkan dengan segera tanpa perlu menghentikan pengujian seperti yang terjadi pada piranti lunak SARD versi sebelumnya,

- memungkinkan komunikasi data dengan sejumlah komputer yang berbeda dalam jaringan tertentu, sehingga memungkinkan analis data melalukan analisis numerik secara terpisah tanpa mengganggu keberlangsungan pengujian secara waktu nyata.

B. Piranti Lunak Presentasi Data Waktu Nyata Mobile

Piranti lunak presentasi data waktu nyata berbasis mobile dikembangkan sebagai pendukung bagi fungsionalitas presentasi data standard yang dimiliki piranti lunak utama SARD untuk memungkinkan pemantauan fluktuasi data, tidak hanya pada saat pengujian berlangsung, namun juga pada tahap persiapan pengujian, seperti kalibrasi instrumentasi dan uji fungsional, di tempat yang terpisah dari komponen utama SARD [6]. Dengan mengimplementasikan piranti lunak pendukung ini pada perangkat mobile, seperti smartphone dan tablet, pengguna bisa memanfaatkan fungsionalitas presentasi yang sama tanpa harus berurusan dengan masalah perkabelan ataupun komunikasi orang-ke-orang yang kompleks melalui handy talkie yang sering terjadi sebelum piranti lunak pendukung ini dimanfaatkan.

Gambar 5 menunjukkan antarmuka pengguna grafis dari piranti lunak pendukung ini yang terinstalasi tablet Android. Beberapa fitur utama dari piranti lunak pendukung ini adalah sebagai berikut :

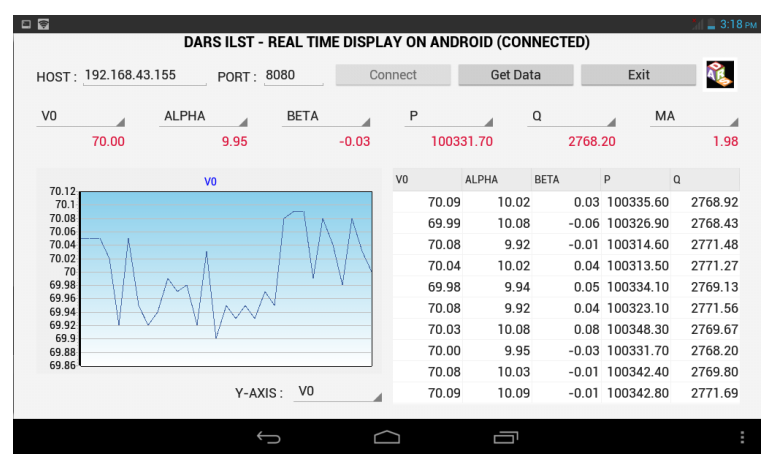

Gambar 5. Antarmuka piranti lunak presentasi data waktu nyata mobile di tablet Android.

- menampilkan data aerodinamika yang telah terolah dalam bentuk numerik dan plot/grafis secara waktu nyata,

- memungkinkan pengguna memilih data yang ingin ditampilkan dengan segera tanpa menghentikan pengujian,
- memungkinkan implementasi skema client-server secara simultan, dimana sejumlah perangkat mobile bertindak sebagai client dan berinteraksi dengan komputer dimana piranti lunak utama SARD terinstalasi yang bertindak sebagai server, sehingga memungkinkan sejumlah pengguna memantau data pengujian di perangkat mobilenya masing-masing.

C. Piranti Lunak Sistem Informasi Pendukung Pengujian Terowongan Angin

Piranti lunak sistem informasi pendukung pendukung pengujian terowongan angin dikembangkan untuk menjawab tuntutan kebutuhan baik dari pihak tim pelaksana pengujian maupun pihak pengguna layanan pengujian yang menginginkan informasi tentang progress pengujian dalam bentuk yang sistematis sehingga mereka dapat mengambil keputusan tertentu untuk mengantisipasi berbagai kemungkinan, seperti kendala yang timbul selama pengujian berlangsung, berdasarkan informasi tersebut [7].

Gambar 6 menunjukkan antarmuka pengguna grafis dari piranti lunak pendukung ini. Beberapa fitur utama dari piranti lunak pendukung ini adalah sebagai berikut :

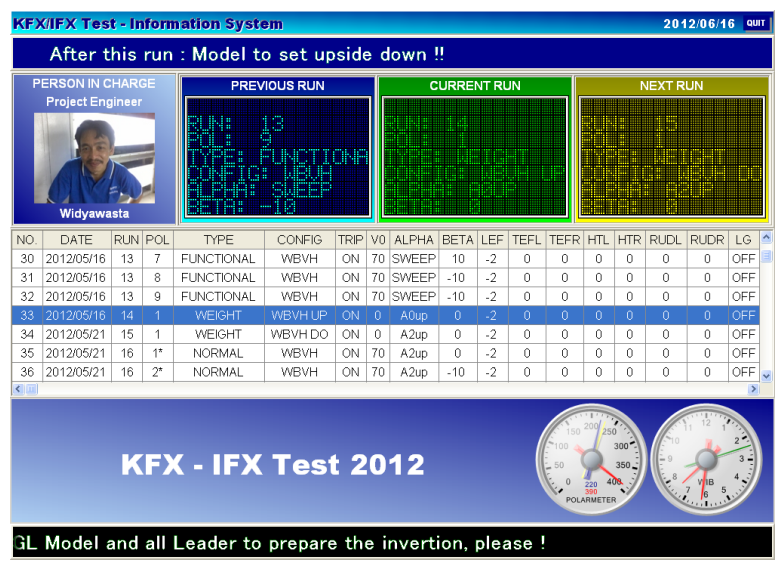

Gambar 6. Antarmuka piranti lunak sistem informasi pendukung pengujian terowongan angin.

- menampilkan properti/atribut dari pengujian yang telah, yang sedang dan yang akan dilaksanakan secara waktu nyata,

- memungkinkan pengguna menginput data log pengujian dan menampilkannya dalam bentuk tabular (grid),

- memungkinkan pengguna menginput teks informasi dan menampilkannya dalam bentuk scroll text sehingga memungkinkan penyampian pesan penting atau peringatan kritikal bagi operator dan client,

- menampilkan jumlah satuan pengujian yang telah dilaksanakan, jumlah satuan pengujian yang dianggap sukses, dan jumlah satuan pengujian 
yang gagal, sehingga kepala tim pengujian dapat mengevaluasi data-data tersebut untuk mengambil tindakan perbaikan yang diperlukan,

- memungkinkan pengguna menyimpan data log pengujian ke berkas log untuk penggunaan lebih lanjut.

D. Piranti Lunak Pengelola Parameter Akuisisi Data

Piranti lunak pengelola parameter akuisisi data dikembangkan untuk mendukung operator akuisisi data dalam mengelola parameter akuisisi data yang kompleks sebelum pengujian dilaksanakan melalui antarmuka yang ramah pengguna [8]. Fungsionalitas ini tidak tersedia baik di piranti lunak utama SARD versi sebelumnya maupun versi saat ini, sehingga memotivasi dikembangkannya piranti lunak pendukung ini agar operator, khusus operator pemula, tidak perlu bersusah payah berjuang untuk mengingat dan mengetahui seluk beluk struktur parameter akusisi data yang sangat rumit.

Gambar 7 menunjukkan antarmuka pengguna grafis dari piranti lunak pengelola parameter akuisisi data. Beberapa fitur utama dari piranti lunak pendukung ini adalah sebagai berikut :

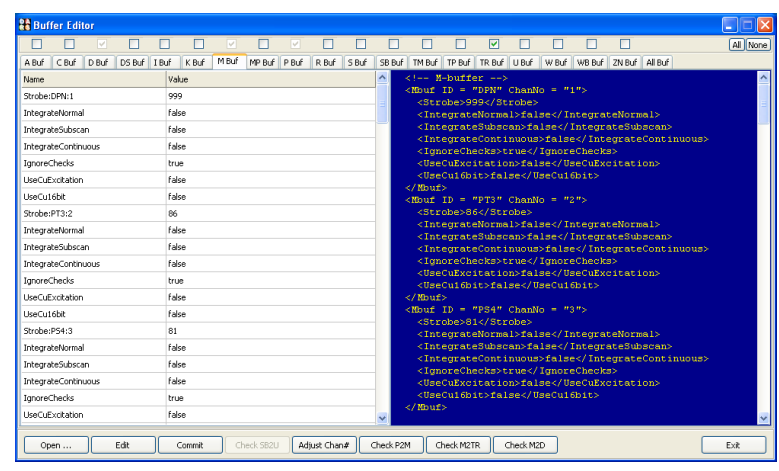

Gambar 7. Antarmuka piranti lunak pengelola parameter akuisisi data.

- menampilkan parameter akusisi data dalam bentuk tabular (grid) dan format Extensible Markup Language (XML) sesuai spesifikasi standard SARD,

- memungkinkan pengguna melakukan input, edit dan penghapusan nilai-nilai parameter akuisisi data dengan antarmuka yang ramah pengguna,

- memungkinkan pengguna menyimpan parameter akuisisi data ke berkas sehingga dapat dimuat kembali bila diperlukan,

- memungkinkan pengguna melakukan verifikasi dan validasi antar struktur parameter yang saling berelasi, sehingga mencegah timbulnya struktur parameter yang tidak valid.

E. Piranti Lunak Pengelola Aktivitas Perekayasa

Piranti lunak pengelola kegiatan Perekayasa dikembangkan untuk memenuhi kebutuhan para
Perekayasa sebagai pelaksana pengujian terowongan angin untuk mencatat kegiatannya sehingga mereka dapat merencanakan, menelusuri dan mengajukan penilaian angka kredit atas kinerja kegiatan yang telah dilakukan selama terlibat dalam kegiatan pengujian dan kegiatan kerekayasaan lainnya guna mengembangkan karirnya sebagai Perekayasa [9-11]. Meskipun tidak terkait secara langsung dengan fungsionalitas piranti lunak SARD, piranti lunak pendukung ini berperan penting khususnya dalam memotivasi para Perekayasa agar tidak melupakan perekaman kegiatan mereka. Piranti lunak pendukung ini awalnya diprototipekan dengan Microsoft Excel dan selanjutnya telah dikembangkan untuk diaplikasikan pada platform web guna memungkinkan perekaman kegiatan kerekayasaan secara mobile melalui koneksi internet.

Gambar 8 menunjukkan antarmuka pengguna grafis dari piranti lunak pengelola aktivitas Perekayasa. Beberapa fitur utama dari piranti lunak pendukung ini adalah sebagai berikut :

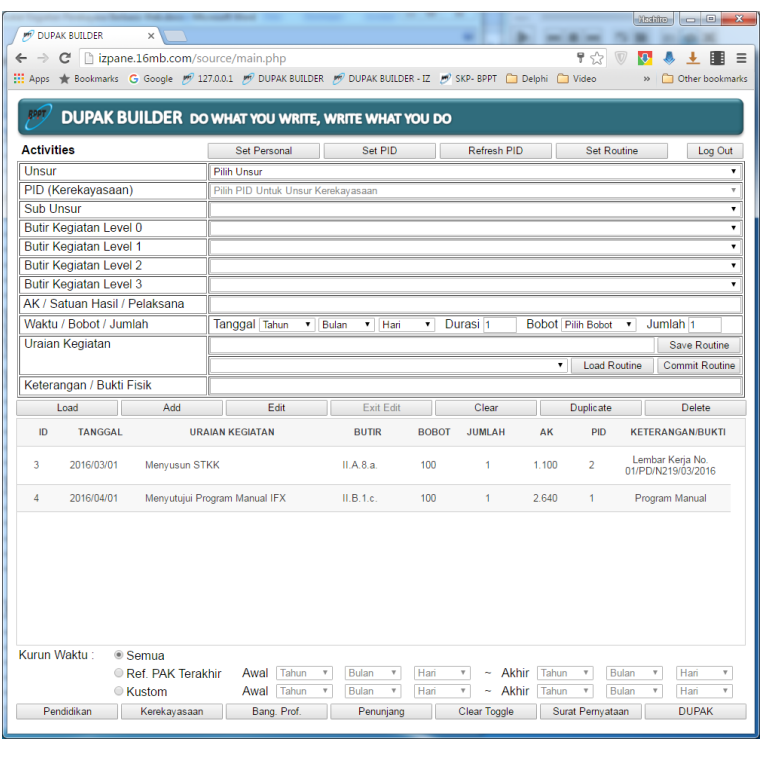

Gambar 8. Antarmuka piranti lunak pengelola aktivitas Perekayasa.

- memungkinkan pengguna melakukan input, edit dan penghapusan data kegiatan dengan antarmuka yang ramah pengguna sesuai petunjuk teknis yang berlaku [12],

- memungkinkan pengguna mengevaluasi angka kredit yang telah dicapai untuk merencanakan pengajuan evaluasi penilaian angka kredit,

- memungkinkan pengguna mencetak secara otomatis Surat Pernyataan Pelaksanaan Kegiatan dan Daftar Usulan Penetapan Angka Kredit sebagai dokumen untuk pengajuan evaluasi penilaian angka kredit.

F. Piranti Lunak Pengolah Data Pasca Pengujian

Piranti lunak pengolah data pasca pengujian dikembangkan untuk memenuhi kebutuhan pengolahan 
data setelah dirampungkannya suatu pengujian untuk keperluan analisis dan evaluasi lebih lanjut, baik bagi pihak pelaksana pengujian maupun pihak client sebagai pengguna layanan pengujian [13]. Piranti lunak pendukung ini awalnya diprototipekan dengan Microsoft Excel dan selanjutnya sedang dikembangkan untuk dapat diaplikasikan pada platform web guna memungkinkan penggunaan secara bersama secara terdistribusi (distributed sharing) melalui koneksi internet di antara pemegang kepentingan.

Gambar 9 menunjukkan prototipe antarmuka pengguna grafis dari piranti lunak pengolah data pasca pengujian. Beberapa fitur utama dari piranti lunak pendukung ini adalah sebagai berikut :

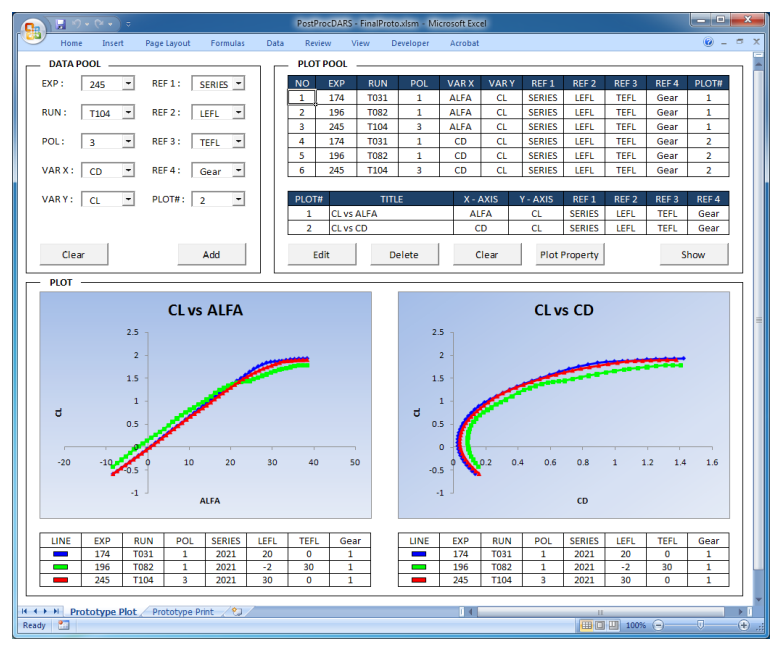

Gambar 9. Prototipe antarmuka piranti lunak pengolah data pasca pengujian.

- memungkinkan pengguna melakukan pemilihan data pengujian yang akan diolah,

- memungkinkan pengguna menampilkan data terpilih secara terkomparasi dalam bentuk plot/ grafik,

- memungkinkan pengguna mengatur format plot/ grafik sesuai kebutuhan,

- memungkinkan pengguna menampilkan data terpilih dalam bentuk numerik.

\section{G. Piranti Lunak Pembangun Bagan Tim Uji}

Piranti lunak pembangun bagan tim uji dikembangkan untuk memenuhi kebutuhan pengelolaan tim pelaksana pengujian, khususnya dalam penentuan sumber daya manusia yang memenuhi kriteria berdasarkan kompetensi, peran dan tugas yang akan diemban, serta alokasi beban kerja yang manusiawi berdasarkan jam kerja yang diatur petunjuk teknis [14]. Piranti lunak pendukung ini awalnya diprototipekan dengan Microsoft Excel dan selanjutnya sedang dikembangkan untuk dapat diaplikasikan pada platform web guna memungkinkan penggunaan secara bersama secara terdistribusi (distributed sharing) melalui koneksi internet di antara pemegang kepentingan.

Gambar 10 menunjukkan prototipe antarmuka pengguna grafis dari piranti lunakpembangun bagan tim uji. Beberapa fitur utama dari piranti lunak pendukung ini adalah sebagai berikut :

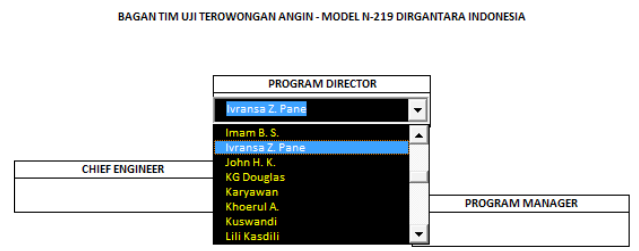

Gambar 10. Prototipe antarmuka piranti lunak pembangun bagan tim uji.

- memungkinkan pengguna mementukan struktur bagan berdasarkan tipe organisasi yang tersedia sesuai petunjuk teknis,

- memungkinkan pengguna melakukan pemilihan personil berdasarkan peran yang akan diembankan,

- memungkinkan pengguna melakukan analisis dan evaluasi beban kerja personil,

- mendukung pengguna dalam pengambilan keputusan pada saat pembentukan tim uji berdasarkan data-data dari hasil analisis.

\section{INTEGRASI PIRANTI LUNAK DAN DISKUSI}

Integrasi piranti lunak pendukung dengan piranti lunak utama SARD dilaksanakan menurut prosedur yang diuraikan di bagian metodologi. Dalam evaluasi tahap awal, terpilih lebih dari sepuluh kandidat piranti lunak pendukung yang layak untuk dikembangkan. Namun, keterbatasan di sisi sumber daya manusia pengembangan piranti lunak dan adanya level prioritas yang menghendaki didahulukannya pengembangan 10 piranti lunak pendukung, maka secara bertahap 7 piranti lunak pendukung yang telah diuraikan sebelumnya dibangun dengan metodologi prototyping. Sementara piranti lunak pendukung lainnya, seperti piranti lunak pembangun rencana pengujian terowongan angin, piranti lunak preparasi instrumentasi pengujian and piranti lunak evaluasi kerampungan pengujian, menyusul untuk didorong ke slot prototyping pada giliran berikutnya.

Ide fundamental dalam integrasi piranti lunak pendukung didasarkan pada kenyataan bahwa pengujian terowongan angin pada prinsipnya dilaksanakan dalam tiga fase, yaitu fase pra-uji, fase eksekusi, dan fase pasca-uji. Aktivitas dalam fase prauji meliputi preparasi instrumentasi, perencanaan tim uji, penjadwalan unit uji, dan konfirmasi kesiapan SARD. Aktivitas dalam fase eksekusi meliputi pengaturan konfigurasi uji, kalibrasi SARD sebelum

\section{ULTIMATICS, Vol. VIII, No. 1 | Juni 2016}


setiap satuan uji dilaksanakan, operasi akuisisi data, dan pengolahan data menjadi bentuk yang dapat dipresentasikan, seperti tabulasi numerik dan plot/ grafik. Sedangkan aktivitas dalam fase pasca-uji meliputi pengolahan data pasca uji ke dalam format yang ditentukan oleh client, validasi data uji, evaluasi kerampungan pengujian, dan penyelesaian kontrak uji dengan client. Meskitidak merepresentasikan pengujian secara keseluruhan, aktivitas-aktivitas dalam tiap fase yang diuraikan sebelumnya merupakan kumpulan aktivitas tipikal, bila dipandang dari sudut pandang rekayasa piranti lunak, memiliki nilai yang perlu dipertimbangkan signifikansinya dan dikonversikan ke dalam bentuk piranti lunak pendukung. Nilai yang dimaksud dalam konteks ini adalah manfaat, tidak hanya dalam mendukung fungsionalitas yang sudah ada di piranti lunak utama SARD, namun juga dalam mendukung aspek manajerial, khususnya yang terkait dengan kendali mutu pengujian terowongan angin. Berdasarkan argumen ini, sejumlah skema integrasi telah diusulkan dan salah satu yang memiliki kemungkinan besar untuk dapat diwujudkan dalam waktu dekat adalah skema yang ditunjukkan dalam Gambar 11

Seperti yang ditunjukkan dalam Gambar 11, integrasi seluruh piranti lunak didasarkan pada satu fondasi, yaitu komitmen dasar terhadap kendali mutu dari pengujian terowongan angin. Hal ini dimaksudkan guna menjaga proses pengembangan dan integrasi piranti lunak pendukung tetap memenuhi komitmen manajemen TAKRI untuk menyediakan hasil uji yang memuaskan pengguna layanan. Pada fase eksekusi, piranti lunak utama SARD, yang memiliki fungsionalitas standard dalam akuisisi, pengolahan dan presentasi data, didukung oleh dua piranti lunak pendukung di sisi input, yaitu piranti lunak pengelola parameter akusisi data, yang memudahkan operator dalam pengaturan konfigurasi parameter akusisi data sebelum pengujian dilaksanakan, dan piranti lunak operator akuisisi data, yang menyediakan antarmuka ramah pengguna bagi operator selama eksekusi pengujian berlangsung. Data dari piranti lunak utama SARD selanjutnya ditransmisikan ke dua piranti lunak pendukung lainnya, yaitu piranti lunak presentasi data waktu nyata mobile, yang memungkinkan personil terotorisasi untuk memantau data pada perangkat mobilenya, dan piranti lunak sistem informasi pendukung pengujian terowongan angin, yang menampilkan status progress pengujian terowongan angin selama eksekusi pengujian berlangsung

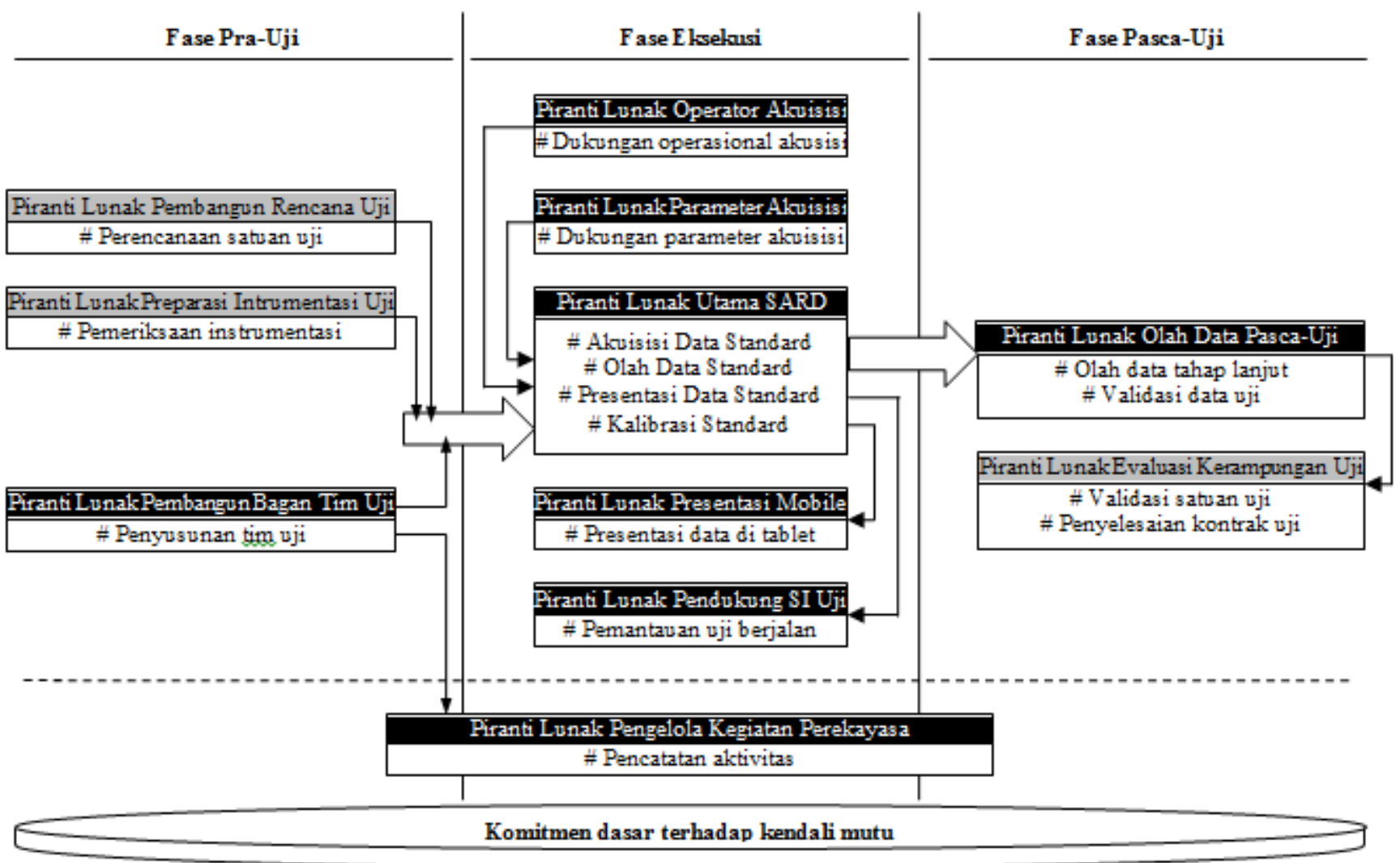

Tengah dikemb angkan Rencana dikemb angkan

Gambar 11. Skema integrasi piranti lunak pendukung dan piranti lunak utama SARD. 
Kebutuhan akan piranti lunak pendukung di fase eksekusi menjadi prioritas utama karena dukungannya besifat fungsional langsung terhadap keberhasilan eksekusi pengujian, sehingga pengembangan piranti lunak pendukung di fase ini hampir memasuki tahap akhir. Sedangkan piranti lunak pendukung di fase prauji dan pasca-uji baru memasuki siklus prototyping tahap awal, seperti piranti lunak pembangun bagan tim uji dan piranti lunak pengolah data pasca-uji. Sementara piranti lunak pendukung di kedua fase ini masih dalam rencana untuk dikembangkan. Piranti lunak preparasi instrumentasi pengujian direncanakan untuk dikembangkan guna melakukan validasi dan verifikasi kesiapan instrumentasi pengukuran sebelum digunakan dalam pengujian. Hasil keluaran dari piranti lunak pendukung ini selanjutnya akan dikirim ke piranti lunak utama SARD untuk dijadikan sebagai referensi ketersediaan instrumentasi. Piranti lunak pembangun rencana pengujian direncanakan untuk dikembangkan guna mendukung manajer pengujian dalam merencanakan waktu eksekusi satuan uji beserta perangkat sumber daya manusia yang melaksanakannya. Hasil keluaran dari piranti lunak pendukung ini bersama hasil keluaran dari piranti lunak pembangun bagan tim uji selanjutnya ditransmisikan ke piranti lunak utama SARD sebagai referensi manajerial dalam alokasi waktu dan personil pelaksanaan pengujian. Piranti lunak dalam fase pascauji yang direncanakan untuk dikembangkan adalah piranti lunak evaluasi kerampungan pengujian, yang menerima hasil keluaran dari piranti lunak pengolah data pasca pengujian untuk memeriksa jumlah satuan uji yang valid dan menyelesaikan kontrak uji dengan pengguna layanan pengujian terowongan angin.

Terdapat satu piranti lunak pendukung yang digunakan baik di fase pra-uji, fase eksekusi maupun fase pasca-uji, yaitu piranti lunak pengelola kegiatan Perekayasa. Sebagaimana dijelaskan sebelumnya, keberadaan piranti lunak pendukung ini diharapkan dapat mendukung para Perekayasa sebagai pelaksana pengujian terowongan angin dalam merekam kegiatannya di setiap fase pelaksanaan pengujian. Piranti lunak pendukung ini membutuhkan hasil keluaran dari piranti lunak pembangun bagan tim uji untuk memungkinkan Perekayasa mengetahui peran dan alokasi waktu mereka dalam tim pengujian sebelum mereka merencanakan kegiatan.

\section{KESIMPULAN}

Pengembangan piranti lunak pendukung SARD dari TAKRI telah dilaksanakan melalui rangkaian siklus prototyping. Skema integrasi piranti-piranti lunak pendukung ini dengan piranti lunak utama SARD telah diusulkan berdasarkan fase-fase dalam pelaksanaan pengujian terowongan angin dan fondasi kendali mutu. Sejumlah piranti lunak pendukung direncanakan untuk dikembangkan dalam waktu dekat untuk mewujudkan piranti lunak SARD yang terintegrasi secara penuh guna menyediakan fungsionalitas dari fase prauji hingga pasca-uji. Integrasi ini diharapkan dapat berkontribusi dalam menyediakan hasil pengujian yang memusakan pengguna layanan.

\section{DAFTAR PUSTAKA}

[1] R.S. Pressman, "Software Engineering, A Practitioner's Approach, Seventh Edition," McGraw Hill, 2010.

[2] I. Sommerville, "Software Engineering, Ninth Edition," Pearson, 2010.

[3] I.Z. Pane, "Pemanfaatan Microsoft Excel Sebagai Perangkat Pengembangan Prototipe Piranti Lunak Visual", ULTIMA InfoSys, Vol. VI No. 1, 2015, pp. 20-26.

[4] I.Z. Pane, "Eksplorasi Aspek Keramahgunaan Prototipe Piranti Lunak Operator Akuisisi Data Terowongan Angin Kecepatan Rendah Indonesia”, Prosiding Seminar Nasional Multidisiplin Ilmu, Universitas Budi Luhur, Jakarta, 10 Mei 2014, pp. A-255-A-261.

[5] I.Z. Pane, "Pengembangan Prototipe Kontemporer Piranti Lunak Akuisisi dan Reduksi Data Terowongan Angin Kecepatan Rendah Indonesia" ULTIMA Computing, Vol. VI No. 1, 2014, pp. 18-24.

[6] I.Z. Pane, "Rekayasa Prototipe Piranti Lunak Presentasi Data Waktu Nyata Terowongan Angin Kecepatan Rendah Indonesia Pada Perangkat Mobile Android" ULTIMATICS, Vol. VI No. 1, 2014, pp. 26-29.

[7] I.Z. Pane, "Rancang Bangun Sistem Informasi Pendukung Pengujian Terowongan Angin Kecepatan Rendah Indonesia", ULTIMATICS, Vol. VI No. 2, 2014, pp. 79-84.

[8] I.Z. Pane, "Rancang Bangun Piranti Lunak Pengelola Parameter Akuisisi Data Terowongan Angin Kecepatan Rendah Indonesia", ULTIMATICS, Vol. VII No. 1, 2015, pp. 55-63.

[9] I.Z. Pane, "Pengembangan Prototipe Piranti Lunak Sistem Informasi Manajemen Kegiatan Perekayasa dengan Microsoft Excel”, ULTIMA InfoSys, Vol. V No. 2, 2014, pp. 54-60.

[10] I.Z. Pane, "Analisis dan Perancangan Piranti Lunak Pencatat Kegiatan Perekayasa Berbasis Web", Prosiding Seminar Nasional Multidisiplin Ilmu, Universitas Budi Luhur, Jakarta, 21 November 2015, pp. ICT-83-ICT-92.

[11] I.Z. Pane, "Implementasi Piranti Lunak Pencatat Kegiatan Perekayasa Berbasis Web", Prosiding Seminar Nasional Multidisiplin Ilmu, Universitas Budi Luhur, Jakarta, 21 November 2015, pp. ICT-38-ICT-49.

[12] Peraturan Kepala Badan Pengkajian dan Penerapan Teknologi No. 10 Tahun 2013 tentang Petunjuk Teknis Jabatan Fungsional Perekayasa dan Angka Kreditnya.

[13] I.Z. Pane, "Rancang Bangun Piranti Lunak Pengolah Data Pasca Pengujian Terowongan Angin Kecepatan Rendah Indonesia”, ULTIMATICS, Vol. VII No. 2, 2015, pp. 131-138.

[14] I.Z. Pane, "Rancang Bangun Prototipe Piranti Lunak Pembangun Bagan Tim Uji Terowongan Angin Kecepatan Rendah Indonesia", Prosiding Seminar Nasional Pengembangan Aktual Teknologi Informasi, UPN Veteran Jatim, Surabaya, 2 Desember 2015, pp. R3.3-1-R3.3-5. 